\title{
Review: Pemanfaatan Tanaman Apotek Hidup Pada Lahan Pekarangan Era Pandemi
}

\author{
Luluk Syahr Banu \\ Program Studi Agroteknologi Fakultas Pertanian Universitas Respati Indonesia \\ Email: luluksyahrbanu@gmail.com
}

\begin{abstract}
ABSTRAK
Pandemi COVID 19 yang menyerang dunia termasuk Indonesia sejak Maret 2020 menyebabkan banyak permasalahan di tengah masyarakat. Masalah perekonomian hingga kesehatan yang paling banyak berdampak dalam era pademi ini. Selain itu, ketahanan pangan dan kesehatan keluarga juga menjadi hal yang tidak kalah penting untuk segera ditanggulangi. Kegiatan yang dapat dilakukan dan enjadi salah satu solusi dalam masalah tersebut adalah dengan menjaga ketahanan pangan dan obat secara mandiri yaitu dengan menjadikan lahan pekarangan sebagai tempat penanaman tanaman apotek hidup dan beberapa tanaman berguna lainnya. Budidaya tanaman obat menjadi salah satu cara untuk meningkatkan nilai kegunaan lahan serta menjadi pertolongan pertama dalam kondisi pandemi untuk menyediakan vitamin maupun khasiat obat-obatan herbal dalam menjaga imunitas keluarga. Kegiatan berbudidaya apotek hidup bisa menjadi kegiatan bermanfaat selama pandemi berlangsung
\end{abstract}

Kata kunci: apotek hidup, pekarangan, pandemi

\begin{abstract}
The COVID-19 pandemic that has attacked the world including Indonesia since March 2020 has caused many problems in society. Economic problems to health that have the most impact in this pandemic era. In addition, food security and family health are also important issues to be addressed immediately. Activities that can be carried out and become one of the solutions to this problem are to maintain food and drug security independently, namely by making the yard as a place for planting live pharmacy plants and several other useful plants. Cultivation of medicinal plants is one way to increase the value of land use and become first aid in a pandemic condition to provide vitamins and the efficacy of herbal medicines in maintaining family immunity. The activity of cultivating a live pharmacy can be a useful activity during the pandemic
\end{abstract}

Keywords: live pharmacy, yard, pandemic

\section{PENDAHULUAN}

Era Pandemi COVID-19 mengakibatkan kecemasan, kekhawatiran dan terhambatnya interaksi sosial, ekonomi dan pendidikan di masyarakat. Dampak negatif yang lain juga menurunkan tingkat kesehatan, pendidikan dan ekonomi masyarakat. sehingga perlu ada upaya untuk mengantisipasi hal ini dengan pemberdayaan masyarakat di era pandemi COVID-19 menuju kehidupan normal baru.
Pemberdayaan masyarakat yang dapat dilakukan adalah berbudidaya secara mandiri dengan menanam tanaman untuk mendukung ketahanan pangan keluarga sampai masalah kesehatan. Masalah lain yang juga muncul bagaimana cara memanfaatkan lahan pekarangan sempit terutama di perkotaan besar supaya lebih bermanfaat. Solusi dari

http://ejournal.urindo.ac.id/index.php/pertanian

Article History : 
masalah-masalah tadi ialah menanam tanaman apotek hidup di lahan pekarangan rumah.

Apotek hidup adalah memanfaatkan sebagian tanah pekarangan rumah untuk ditanami tanaman obat-obatan sebagai keperluan sehari-hari bila ada anggota keluarga yang sakit. Pada umumnya masyarakat lebih menyukai mengkonsumsi obat-obat tradisional. Selain karena faktor ekonomi, obat tradisional umumnya dianggap lebih aman karena bersifat alami dan memiliki efek samping yang lebih sedikit dibandingkan obat-obat buatan pabrik [1]. Penanaman tanaman obat dirasa menjadi tepat sasaran di era pandemi dengan memberdayakan masyarakat untuk tetap aktif di rumah saja dengan berbudidaya tanam tanaman obat. Hal ini juga selaras dengan langkah yang sangat dianjurkan oleh pakar kesehatan adalah menjaga imunitas tubuh, agar menurunkan kemungkinan terserang oleh virus apapun. Obat-obatan tradisional seperti jahe, kunyit, lengkuas, temulawak dan sebagainya disebut-sebut sebaga ibahan-bahan herbal yang dapat meningkatkan imunitas tubuh. Selain itu, berdasarkan statistik data, permintaan akan tanaman obat herbal maupun vitamin dari tumbuhan semakin meningkat di pasaran di era pandemi. Tujuan dari review ini ialah memberikan pen getahuan dan informasi tentang pemanfaatan tanaman apotek hidup di pekarangan pada masa pandemi.
PEMBAHASAN

Potensi tanaman apotek hidup sebagai obat herbal dan vitamin meningkatkan imunitas tubuh

Permasalahan komplek saat pandemi saat ini menjadi permasalahan yang harus segera ditangani. Di Indonesia, menurut data yang dihimpun, tidak sedikit masyarakat yang mengalami berbagai permasalahan psikologis dan kesehatan seperti kecemasan, kegelisahan, kebimbangan dan permasalahan lainnya yang sedikit banyak mengganggu kehidupan seharihari [3]. Selain itu kejenuhan berada di rumah secara terus menerus tanpa kegiatan bermanfaat juga menjadi masalah baru saat pandemi apabila tidak diatasi dengan bijak. Pilihan untuk memanfaatkan lahan pekarangan yang kosong sebagai lahan apotik hidup merupakan langkah yang tepat untuk dilakukan [4].

Setiap rumah akan memiliki sebingkai tanah yang bisa dimanfaatkan untuk dilakukan budidaya tanaman. Tanaman yang dapat dikembang biakan dapat berupa sayuran, buahbuahan, empon-empon dan lain-lain. Kegiatan menanam tersebut bisa dilakukan dengan berbagai cara yang berbeda dan sesuai kebutuhan masing-masing [5]. Tanaman seperti jahe, kunyit, dan tanaman obat lainnya menjadi contoh tanaman apotek hidup yang bisa jadi pilihan untuk berbudidaya di lahan pekarangan rumah yang sempit sekalipun.

Apotek hidup adalah tanaman obat yang digunakan dalam pengobatan berbagai penyakit. Apotek hidup mempunyai 
beragam jenis tanaman obat dengan manfaat kesehatan [6]. Jenis tanaman yang sering digunakan sebagi apotek hidup ialah lidah buaya, sirih, temu lawak, kunyit, jahe, kumis kucing, bawang putih dan lain-lain. Tanamantanaman tersebut dapat dijadikan sebagai alternatif tanaman obat keluarga sebagai pertolongan pertama pada keluarga ketika ada yang sakit. Apotek hidup juga memiliki fungsi dan kegunaan antara lain pemanfaatan lahan kosong di rumah, penyediaan obat maupun rempah di rumah, pengeluaran keluarga menjadi lebih hemat, bahan meracik obat sendiri, memperindah pekarangan rumah dan yang terpenting adalah penyediaan vitamin dan obat tradisional saat imunitas tubuh harus tetap terjaga.

Berikut ini beberapa hasil penelitian tentang tanaman apotek hidup yang memiliki potensi sebagai obat-obatan ataupun peningkat imun tubuh:

1. Jahe. Ekstrak jahe dapat memperbanyak sel pembuluh alami natural killer dan menghancurkan dinding sel virus yang telah menginfeksi inangnya, dalam tubuh manusia [7]. Jahe juga memiliki banyak senyawa aktif yang dapat meningkatkan imun tubuh.

2. Kunyit. Senada dengan tanaman jahe, Kunyit (Curcuma domestica val) merupakan salah satu tanaman yang digunakan untuk pengobatan tradisional. senyawa aktif dalam rimpang kunyit mampu menghambat pertumbuhan jamur, virus, dan bakteri baik Gram positif maupun Gram negatif, seperti E.coli dan Staphylococcus aureus, karena kunyit mengandung berbagai senyawa diantaranya adalah kurkumin dan minyak atsiri [8].

3. Binahong. Tanaman ini banyak berkhasiat menyembuhkan berbagai penyakit seperti pembengkakan hati, meningkatkan vitalitas dan daya tahan tubuh serta beberapa penyakit lainnya [9].

4. Temulawak. Temulawak (Curcuma xanthorrhiza Roxb.) termasuk famili Zingiberaceae dengan bagian yang dimanfaatkan adalah rimpang dan merupakan tanaman asli Indonesia. Dari uji praklinik temulawak dapat dipergunakan sebagai obat antioksidan, hepatoproteksi, antiinflamasi, antikanker, antidiabetes, antimikroba, antihiperlipidemia, anti kolera, anti bakteri [10].

5. Pegagan. Pegagan mengandung bahan aktif yang bermanfaat untuk kesehatan dan meningkatkan sistem imun tubuh, seperti triterpenoid, steroid, saponin dan turunannya, serta garam mineral [11].

6. Lengkuas. Rimpang lengkuas dipercaya dapat meningkatkan imun tubuh manusia [12]

7. Kencur. Tanaman ini juga memiliki banyak khasiat obat. Zat aktif yang terkandung dalam tanaman seperti flavonoid dan minyak atsiri merupakan komponen yang penting dalam menunjang imunitas tubuh. Salah satu tanaman yang mengandung flavonoid 
dan minyak atsiri adalah kencur (Kaemferia galanga L.) [13].

8. Kayu manis. Pada suatu penelitian Pemberian ekstrak C. burmanii pada tikus wistar jantan selama 7 hari dapat meningkatkan aktivitas dan kapasitas fagositosis secara bermakna sehingga bisa disimpulkan bahwa bisa juga meningkatkan imun tubuh manusia [14]

Banyak hal yang perlu diperhatikan dalam penelitian mengenai tanaman apotek hidup terutama khasiatnya sebagai obat dan vitamin peningkat imunitas tubuh namun tidak mengurangi potensi beberapa tanaman yang menjadi alternatif obat kimiawi. Pengetahuan dan informasi lebih lanjut mengenai bagaimana proses senyawa aktif pada beberapa tanaman apotek hidup terus digali sehingga masyarakatpun bisa diberikan informasi secara lengkap dan akurat. Selain itu komposisi dari obat-obatan herbal dan senyawa-senyawa aktif juga bisa disesuaikan dengan standar dosis yang dianjurkan supaya penggunaan obat-obatan alami dari tanaman ini bisa lebih aman dan efektif. Belum ada analisis terkait beberapa tanaman yang dipercaya meningkatkan imun tubuh menjadi konsentrasi penting mengapa penelitian lebih lanjut mengenai hal tersebut perlu lebih banyak dilakukan.

Percobaan yang juga menjadi prioritas yaitu penggunaan lahan pekarangan bahkan yang memiliki ukuran minimal sekalipun baik di pedesaan maupun di kota untuk budidaya tanaman apotek hidup dan berbagai jenis tanaman yang lebih bervariasi. Penelitian lanjutan mengenai pemanfaatan lahan untuk tanaman obat keluarga saat era pandemi covid19 juga menjadi penelitian yang terbarukan dan lebih bermanfaat karena menjawab isu penting mengenai potensi obat-obatan herbal maupun peningkatan aktifitas di bidang pertanian selama pandemi berlangsung. Selama ini berdasarkan beberapa referensi yang didapat, banyak masyarakat yang kurang menyadari pentingnya penggunaan lahan untuk lebih produktif serta khasiat tanaman-tanaman obat yang digunakan sebagai TOGA/apotek hidup. Minimnya informasi mengenai pemanfaatan lahan sebagai tempat menanam tanaman apotek hidup juga belum maksimal.

\section{KESIMPULAN}

Pemanfaatan lahan pekarangan memiliki potensi sebagai tempat budidaya tanaman apotek hidup. Beberapa tanaman apotek hidup seperti jahe, kunyit, pegagan, binahong, kencur, kayumanis, temulawak dan lengkuas bisa menjadi alternatif obat kimiawi sebagai peningkat imunitas tubuh Kegiatan berbudidaya apotek hidup bisa menjadi kegiatan bermanfaat selama pandemi berlangsung

\section{DAFTAR PUSTAKA}

Zainuddin A., Tri Mayanti, dan Jamaludin Al Anshori. 2018. Pengenalan Apotek Hidup Dan Media Penanaman Hidroponik Kepada Ibu-lbu Pkk Di Desa Sayang Kecamatan Jatinangor. https://jurnal.unpad.ac.id/pkm/article/vi ewFile/20263/9686 
Agustin I.N. , Vivian., W. Lius., S. Yoren., M. Phang., N Chris., A. Saudjhana., H. Yonathan, dan Willyana. 2020. Pemanfaatan Lahan Pribadi Sebagai Lumbung Obat Di Era Pandemi Bagi Warga Kelurahan Belian. Prosiding National Conference for Community Service Project (NaCosPro). 2 (1): 68-77

Pranita, E. 2020. 6 masalah psikologis yang paling banyak muncul akibat pandemi covid-19.

https://www.kompas.com/sains/read/20 20/10/21/080500923/6-masalahpsikologis-yang-paling-banyak-munculakibat-pandemi-covid-19?page=all diakses 28 Juni 2021.

A. Hidayatulloh, D. Mahandika, Yuniantoro, dan M.D. Mudzakir. 2018. Pembudidayaan tanaman apotik hidup guna Meningkatkan perekonomian masyarakat. Jurnal Pemberdayaan: Publikasi Hasil Pengabdian kepada Masyarakat. 2 (2): 341-346.

A. N. Soleh., B. Krisbiyanti., J.A. Fahira, dan T. Wulandari. 2020. Upaya pemanfaatan lahan pekarangan rumah untuk budidaya tanaman sayuran sebagai penyedia pangan di masa pandemi covid-19 di desa panjunan rt 012 rw 002 kec. Petarukan, kab. Pemalang. https://kkn.unnes.ac.id/lapkknunnes/320 04_3327102012_6_Desa\%20Panjunan_2 0200922_135249.pdf diakses 28 Juni 2021.
Pratama, R. A. J. 2021. Pengertian Apotek Hidup, Jenis, dan Manfaatnya. https://dosenpertanian.com/apotekhidup/ diakses 29 Juni 2021

Nurlila R. A. Dan J.L. Fua 2020. Jahe Peningkat Sistem Imun Tubuh di Era Pandemi Covid19 di Kelurahan Kadia Kota Kendari. Jurnal Mandala Pengabdian Masyarakat. 1 (2). Desember 2020

Hidayati, E., N. Juli, E. Marwani. 2002. Isolasi Enterobacteriaceae Patogen dari Makanan Berbumbu dan Tidak Berbumbu Kunyit (Curcuma longa L.) Serta Uji Pengaruh Ekstrak Kunyit (Curcuma longa L.) Terhadap Pertumbuhan Bakteri Yang Diisolasi. FMIPA Universitas Nahdlatul Wathan-Mataram. Bandung

Manoi, F. 2009. Binahong (Anredera cordifolia) (Ten) Steenis Sebagai Obat. Jurnal Warta Penelitian Dan Pengembangan Tanaman Industri. 15 (1): 3.

Fatmawati, D.A. 2008. Pola protein dan kandungan kurkuminoid rimpang temulawak (Curcuma xanthorrhiza Roxb.). Skripsi. FMIPA IPB. Bogor.

Sutardi. 2016. Kandungan Bahan Aktif Tanaman Pegagan Dan Khasiatnya Untuk Meningkatkan Sistem Imun Tubuh. Jurnal Litbang Pertanian 35 (3): 121-130.

Adawiyah, R. 2019. Uji Efektivitas Katalitik Herbal Rebusan Rimpang Lengkuas Sebagai Bahan Aktif Penghambat Bakteri Escherichia coli Terhadap Penyembuhan Diare Pada Balita. Jurnal Kimia Fisika. 


\section{Jurnal IImiah Respati}

Rosida. 2019. Potensi ekstrak kencur (Kaemferia Galanga L.) sebagai imunomodulator pada tikus model yang terinfeksi Mycobacterium tuberculosis. Jurnal Ilmiah Farmasi Akademi Farmasi Jember. $3(1)$.

Faishal L. F., A.W. Utomo, dan D. Retnoningrum. 2017. Pengaruh Pemberian Ekstrak Kayu Manis (Cinnamomum burmani) Terhadap Aktivitas Dan Kapasitas Fagositosis Studi Eksperimental Pada Tikus Wistar Yang Dipapar Staphylococcus Aureus. Jurnal Kedokteran Diponegoro. 6 (2). 
Jurnal Ilmiah Respati 